\title{
Farmer's perception on artificial insemination under the mandatory pregnant cow program (UPSUS SIWAB) in West Nusa Tenggara, Indonesia
}

\author{
I Putu Cakra Putra Adnyana*, LuhGde Sri Astiti, Nurul Agustini, Hijriyah, Nurul Hilmiati
}

Assessment Institute for Agricultural Technology West Nusa Tenggara, Jalan Raya Peninjauan

Narmada Lombok 83371 Indonesia

\begin{abstract}
Low cattle productivity has been common in West Nusa Tenggara (WNT) in which feed shortage being a classic problem contributing to slow growth, high calf mortality and long calving interval. The contributing factor is quality bull shortage. One of the efforts that has been madeto improve thecattle productivity is artificial insemination (AI). This study aims to describe farmer perception on artificial insemination in WNT. This study used case study methodology for East Lombok and Sumbawa district. Quantitative and qualitative data were collected using FGD and in-depth interview methods, then analysed descriptively. This study showed that farmer perception on AI in East Lombok was more positive driven by bull scarcity and high price of cross bred calf. Meanwhile farmer perception on AI was less positive in Sumbawa influenced by low conception rates. This was attributed to inaccurate reporting time by farmers, varying inseminator skills and long distance between AI service center and farmer site. The less positive perception towards AI in Sumbawa was exacerbated by high fatality risk for cows giving birth to cross bred calf.
\end{abstract}

\section{Introduction}

West Nusa Tenggara (WNT) province is one of beef cattle center in Indonesia [1] and has a strategic role as a source breeder cattle [2]. Sumbawa and East Lombok District have been centers for cattle production in WNT [3] where Bali cattle (Bos Javanicus) species dominates cattle population in these regions. The cattle production system in WNT is based on limited and grazing land [4]. Intensive cattle farming system is generally found in Lombok Island where farmers keep the cattle in collective pensfor security reasons [5]. Meanwhile, cattle farmers in Sumbawa Island generally practice semi-intensive system where cattle are grazed after crop season. During crop planting season from December to May, cattle are put in fenced land (kebun) or cattle grazing areas called Lareither private or communal owned6]. Mostly, farmers rely on nature as source of feed.

\footnotetext{
* Corresponding author: putucakra@yahoo.co.id
} 
The traditional cattle farming system in WNT has contributed to low production and productivity. This is indicated by low performance of Bali cattle and high rate calf birth mortality, ranging from 20-30\% [7,8]. Another cattle problemin WNT is low conception rates where the $\mathrm{S} / \mathrm{C}$ is 1.72 [9]. According to [10] the problems in the beef cattle breeding industry include (1) high services per Conception(S/C), reaching 2.60; (2) long calving interval(CI), and (3) high the mortality rates of pre-weaning calves, reaching $50 \%$. Another indicatoris that in the pasteasy to find cattle weighing between $400-450 \mathrm{~kg}$, while now cattle weighing $300 \mathrm{~kg}$ are starting to become rare. One of the causes of declining Bali cattle performance in WNT is the inter-provincial trade that exports large high quality male cattle, so that the remaining males are getting smaller. This is exacerbated by irregular maintenance management and traditional farming system especially on Sumbawa Island where inbreeding is suspected [11].

In an effort to increase the cattle production and productivity, the WNT Provincial Government has launched the One Million Cattles (BSS) program. One of the programs that have been implemented to support BSS program success is the Artificial Insemination (AI) program, in line with the Ministry of Agriculture's program of Mandatory Pregnant Cows Special Effort (UPSUS SIWAB) program. SIWAB has main program of increasing cattlepopulation through Artificial Insemination (AI) and Intensification of Natural Mating (INKA). Based on data from BPS WNT (2019), AItarget for 2018 in WNT were 29,600 cows but the realization reached 40,359 cows (136\%). This increase in realization occurred in several districts including East Lombok district by $102 \%$. However, most of this achievement was reached in Lombok districts. This study aims to explore farmers perception on artificial insémination in Lombok régions compare to Sumbawa WNT.

\section{Methodology}

A case study was conducted in East Lombok and Sumbawa districts, intertwined with UPSUS SIWAB assistance program to farmer groups by BPTP-NTB from 2018 to 2020. Quantitative and qualitative data were collected using Focus Group Discussion and indepth interview methods. Respondents involved were co-operator farmers as many as 40 people from 2 farmer groups in East Lombok District and Sumbawa District. The data obtained were analysed by descriptive analysis.

East Lombok and Sumbawa region was selected because they are cattle producing center in WNT and the two districts represent two different cattle farming system, an intensive system in Lombok and semi-extensive system in Sumbawa district. Respondents were selected purposively for those who were involved under assistance of SIWAB program from BPTP-NTB.

\section{Results and discussion}

\subsection{Characteristics of respondents}

The respondents in this study were 40 people consisting of 34 men and 6 women. Female respondents are involved in cattle farming especially in East Lombok Districtfor feed collection and feeding. Farmers women have a dual role in addition to being housewives and also providing income and making decisions in agricultural production activities [12]. Likewise, in the management of the cattle business, the head of the household is the main worker and it is assisted by his wife, especially in managing household expenses [13].

Respondents education is mostly primary school to junior high school, according to [14], the level of education reflects the ability of intellectuality which is the basic asset for a 
person to act and behave. The respondent experiences in raising cattle ranged from 1-10 years (Table 1).

Table 1. Respondents education between Beriri Jarakand Maras Panto Farmers group

\begin{tabular}{|c|c|c|c|c|c|c|c|}
\hline \multirow{2}{*}{ District } & \multirow{2}{*}{$\begin{array}{c}\text { Farmers } \\
\text { Group }\end{array}$} & $\begin{array}{c}\text { Primary } \\
\text { School }\end{array}$ & $\%$ & $\begin{array}{c}\text { Junior } \\
\text { high } \\
\text { School }\end{array}$ & $\%$ & $\begin{array}{c}\text { Senior } \\
\text { High } \\
\text { School }\end{array}$ & $\%$ \\
\hline East Lombok & BeririJarak & 10 & 25.00 & 6 & 15.00 & 2 & 5.00 \\
\hline Sumbawa & Maras Panto & 12 & 30.00 & 9 & 22.50 & 1 & 2.50 \\
\hline
\end{tabular}

The experience of farmers can affect the management of cattle farming because the longer the experience, the knowledge will increase (Table 2). Acceptance of an Innovation Adoption is closel yrelated to the farmers knowledge. The farmer's attitude will shape the farmer's perception on the basis of his knowledge and experience, where a positive attitude willincrease adoption, whereas a negative attitude will reduce the possibility of adoption [15].

Table 2. Respondents' experience of Beriri Jarak and Maras Panto Farmers group

\begin{tabular}{|c|c|c|c|c|}
\hline \multirow{2}{*}{ District } & \multirow{2}{*}{ Livestock Group } & \multicolumn{3}{|c|}{ Respondents' Experience } \\
\cline { 3 - 5 } & & $0-1$ years & $1-10$ years & $>10$ years \\
\hline East Lombok & BeririJarak & 2 & 14 & 2 \\
\hline Sumbawa & Maras Panto & 1 & 18 & 3 \\
\hline
\end{tabular}

\subsection{Cattle sex ratio between bulls and cows}

Respondents' cattle composition was dominated by cows. Cattle sex ratio between bulls and cows is $1: 3$ for Sumbawa District and $1: 5$ for East Lombok District. This is because farmers prefer to keep female cattle so that the female population dominates the population while the male livestock is very limited. Farmer preference for AI was dominated by immental, Limousin and Brangus (Table 3). Farmers prefer crossbreed cattle because the selling price is higher than local cattle. This is in line with the opinion of [16] that choosing the type of cross is preferable because the selling price of the calves resulting from the cross is higher even though the crossed cows require more feed and can reduce reproductive performance.

Table 3. Sex ratio between bulls \& cows in Beriri Jarak and Maras Panto farmers group

\begin{tabular}{|c|c|c|c|c|c|}
\hline \multirow{2}{*}{ Farmers Group } & \multirow{2}{*}{$\begin{array}{c}\text { Total Beef } \\
\text { Cattle }\end{array}$} & \multirow{2}{*}{ Total cow } & \multicolumn{2}{|c|}{$\begin{array}{c}\text { Production Development } \\
\text { (Calf Birth) }\end{array}$} & \multirow{2}{*}{ Total } \\
\cline { 4 - 5 } & & & Males & Females & \\
\hline BeririkJarak & 14 & 69 & 12 & 10 & 105 \\
\hline Maras Panto & 30 & 100 & 24 & 37 & 191 \\
\hline
\end{tabular}

The purpose of raising cattle by farmers is to meet large family needs such as children schooling, building houses and social ceremonies. Farmers usually sell exotic cattle at an average of 0.5 to 1year age with a selling price of up to Rp. 15 million per head, while Bali cattle are sold on average at the age of 2 years for $\mathrm{Rp}$. 9-11 million per head. 


\subsection{Farmers' knowledge of artificial insemination}

Based on the results of the FGD, it was known that $100 \%$ of respondents had heard the term Artificial Insemination (AI) where in East Lombok district $80 \%$ apply AI as compared to only 5\% respondents in Sumbawa (Table 4). Respondents stated that $60 \%$ of the information on AI was obtained from other farmer sand $40 \%$ from extension agents/inseminators. Farmers who apply AI said that natural mating is better than AI. This isbecause the AI success rate of pregnancy per service $(\mathrm{S} / \mathrm{C})$ is lower and natural mating. Morover, natural mating does not need cost. However, in this area it is difficult to find farmers who keep bulls, because there is a belief from farmers that if they keep bulls too often mated with females, the cattles are difficult to get fat. In addition, thereis no compensation fee charged for one natural mating and only social or mutual assistance. This condition causes farmers to be less interested in keeping bulls. A similar opinion was conveyed by [17] that AI technology is a solution to mating cows in an area of scarce bulls.

Table 4. Mating Methods for cattle in Beriri Jarak and Maras Panto farmers group

\begin{tabular}{|c|c|c|c|c|c|}
\hline \multirow{2}{*}{ District } & \multirow{2}{*}{ Farmers Group } & \multicolumn{5}{|c|}{ Application of AI } \\
\cline { 3 - 6 } & & AI & $\%$ & Natural Mating & $\%$ \\
\hline East Lombok & BeririJarak & 15 & 83.33 & 3 & 16.67 \\
\hline Sumbawa & Maras Panto & 1 & 4.55 & 21 & 95.45 \\
\hline
\end{tabular}

Out of the 45 AI cows, more than $50 \%$ did not get pregnant in the first service, majority of this group got pregnant in the second service. Few other farmers had to get five services (Table 5). Meanwhile, the other $47 \%$ of the 45 cows got pregnant in the first service. According to [18] that the success of AIwith the $\mathrm{S} / \mathrm{C}$ indicator for Bali cattle is 1.72 while Hoesni [19] states that the $\mathrm{S} / \mathrm{C}$ in Batanghari district for Bali heifers is 2.22 and for Bali cows that have had calves 2.04. Meanwhile, according to [20], the S/C of Bali cattle at the AI in Pringsewu district is between 1-6 times and 1.77 according to (2019) [21] in Kuantan Singingi district.

Table 5. Service per conception rate of AIapplication

\begin{tabular}{|c|c|c|}
\hline S / C AI & Number of cows (head) & $\%$ \\
\hline $1 \mathrm{x}$ & 21 & 47.00 \\
\hline $2 \mathrm{x}$ & 18 & 40.00 \\
\hline $3 \mathrm{x}$ & 4 & 9.00 \\
\hline $5 \mathrm{x}$ & 2 & 4.00 \\
\hline Total & 45 & 100.00 \\
\hline
\end{tabular}

Total 50\% farmers were applied AI as the main choice in mating their livestock because the bulls are lacking. Besides, 30\% of farmers doubt the success of AI. Farmers who expressed doubts because of the risk to cows 7.5\% and the cost of AI which is more expensive than natural mating cow $7.5 \%$ (Table 6). The 5\% farmers doubts were also caused by the lack of training from extension agent or related institutions, so that farmers did not want to apply AI as the first choice. According to [22], the implementation of AI can improve the genetic quality and income of farmers but must be supported by the government in its development. Meanwhile, according to [23] there are several factors inhibiting the application of AI, including profit, innovation compatibility, social systems, personal communication and extension. 
Table 6. Farmers perceptions on AI implementation

\begin{tabular}{|r|c|c|}
\hline Farmers Perceptions of Breeder AI & (person) & $\%$ \\
\hline $1 . \quad$ No male (bull) & 20 & 50.00 \\
\hline $2 . \quad$ Low success & 12 & 30.00 \\
\hline $3 . \quad$ CowRisks & 3 & 7.50 \\
\hline $4 . \quad$ Cost of AI & 3 & 7.50 \\
\hline 5. $\quad$ Extension & 2 & 5.00 \\
\hline Total & 40 & 100.00 \\
\hline
\end{tabular}

\subsection{Experience of artificial insemination (Al)}

The main reason farmers use AI to breed their Bali cows is that there are no bulls in the natural mating area. For example, in Labangka Village, Sumbawa Regency, there is a male shortage because the males in the pasture are converted to fattening cows so that the remaining bulls are young males with an age range of $1-1.5$ years [24]. Besides that, the selling value of the offspring of the results of AI is more expensive than natural breeding.

Farmers with AI experience between 1-4 years stated that they have used AI as the main choice in mating their cows. The number of farmers who have used AI for a long time is because farmers have good experience with AI. A similar opinion was conveyed by [25] that farmers who have tried AIand have good experience with AI will increase farmers' interest in AI. However, farmers who are not experienced in matingcows with AI, still doubt whether AI can solve their problems in increasing the population of their livestock. So, it is necessary to provide more intensive dissemination so that farmers have a good perception of AI.

\subsection{Constraints to artificial insemination (Al)}

The obstacles to the application of AI according to respondents included the low success of AI causing prolonged calving interval, the cost of raising calves resultingf rom AIi s more expensive, distance between AI service center and farmer site is very long, Bali cows have a small body size so that the risk of death of the cow and calf is higher, the high cost of AI and less skilled inseminators. To overcome these obstacles, it is necessary to optimize extension activities, subsidize prices, increase the number and skills of inseminators, and increase cement froms uperior local cows. [26-28] state that the constraints of AI include inseminator skills and expensive AI costs.

\section{Conclusions and recommendations}

Based on the results of the study, it can be concluded that farmer perception on AI in East Lombok was more positive with bull scarcity and high price of cross bred calf as the main drivers. Meanwhile farme rless positive perception against AI in Sumbawa was influenced by low the conception rates. This was attributed to reporting time by farmers, inseminator skills and distance between AI service center and farmer site. This was exacerbated by high fatality risk for cows giving birth to cross bred calf.

To increase the success of AI, itrequirespolicy support from the local government as well as more intensive counseling on the management of cattle reproduction, so that farmers have more knowledge and understanding of $\mathrm{AI}$ in order to improve the implementation and success of $\mathrm{AI}$ in the future. 


\section{References}

1. A. M. Bamualim. Jurnal Pengembangan Inovasi Pertanian.4,3(2011).

2. Dinas peternakan provinsi NTB. Laporan Dinas Peternakan provinsi NTB (2014).

3. L.G.S. Astiti. Pengklusteran Potensi Peternakan di Kabupaten Sumbawa. Prosiding Seminar Nasional Balai Pengkajian Teknologi Pertanian NTT (2015).

4. A. Sodiq, Suwarno, F.R. Fauziyah, Y.N. Wakhidati, P. Yuwono. Agripet.17,1 (2017).

5. Mashur. Jurnal Ilmiah Biologi Bioscientist.2, 1 (2014).

6. N. Hilmiati, A. Muzani, M.S. Mokhtar. 2018. Laporan Kegiatan SIWAB BPTP NTB. Mataram (2018).

7. Dinas peternakan provinsi NTB. 2010. Blueprint NTB BSS (2010).

8. S. Baco, S.B. Wello, R. Malaka dan M. Hatta. Tingkat Kematian dan Pertumbuhan Pedet Sapi Bali melalui Perbaikan Managemen dengan Intervensi Pakan Konsentrat Berbahan Lokal. Prosiding Seminar Nasional Peternakan Universitas Hasanudin Makasar. (2015).

9. K.Y. Samberi, N. Ngadiyono, Sumadi. BuletinPeternakan. 34, 3 (2010)

10. P.U. Hadi dan N. Ilham. Jurnal Litbang Pertanian. 21, 4 (2002)

11. N. Ilham. 2001. WARTAZOA. 11,2 (2001).

12. E.P. Rini, I.M.N. Tenaya, N.W.S. Astiti. Jurnal Manajemen Agri bisnis. 2, 1 (2014)

13. M. Sulistyati, Hermawan, dan A. Fitriani. Jurnal Ilmu Ternak. 13,1 (2013)

14. S.P. Robbins. Jakarta (ID):PrenhaHindo (2003)

15. S.S. Meijer, D. Catacutan, C. Oluyede, W.G. Ajayi, M. Silehi and Nieuwenhuis. International Journal of Agricultural Sustainability.13,1(2015)

16. D. Kusumo dan I. Inounu. Wartazoa. 367, (2018)

17. S. Baba dan M. Risal. Preferensi dan Tingkat Pengetahuan Peternak Tentang Teknologi IB di Kabupaten Barru. Prosiding Seminar Nasional Peternakan Universitas Hasanudin Palu,(2015)

18. Jalius. Jurnal Agrinak.1, 1 (2011)

19. F. Hoesni. Jurnal Ilmiah Universitas Batanghari Jambi. 15, 4 (2015)

20. F. Febrianthoro, M. Hartono dan S. Suharyati. Jurnal Ilmiah Peternakan Terpadu. 3, 4(2015)

21. R. Pratami, D. Kurnia dan P. Anwar. Journal of Animal Center.1, 2 (2019)

22. M. Sibagariang, Z. Lubis, Hasnudi. Agrica (Jurnal Agribisnis Sumatera Utara). 3, 2 (2010)

23. S.Y. Pateda. Saintek. 5, 1(2010)

24. N. Hilmiati. Jurnal sosial-ekonomi pertanian.13, 2 (2019)

25. S.N. Sirajuddin, I.M. Said, S. Syawal dan J. Alwi. Jurnal Ilmu dan Industri Peternakan.1, 3 (2014).

26. T. Herawati, A. Anggraeni, L. Praharani, D. Utami dan A. Argiris. Jurnal Informatika Pertanian 21, 2(2012)

27. L.D. Bahar, S. Baba dan S.N. Sirajudin. Hambatan Adopsi Teknologi Inseminasi Buatan oleh Paternak Sapi Bali di Kecamatan Sopeng Riaja Kabupaten Barru. Prosiding Seminar Nasional Sumberdaya Lokal pada Peternakan Rakyat. Universitas Hasanuddin. Makasar, (2014)

28. T.B. Purwantini. Optimalisasi Inseminas iBuatan (IB) mendukung Percepatan Produksi dan Swasembada Daging Sapi. Prosiding Seminar Nasional Swasembada Pangan. Politeknik Negeri Lampung, (2015) 